POLYÁK Ildikó - ANDRÁSI Gábor - KÉRY Dóra - TARDOS Katalin

\title{
INTERKULTURÁLIS KOMPETENCIA ÉS SZERVEZETI MÉRÉSÉNEK LEHETŐSÉGEI
}

A tanulmány az IBS Nemzetközi Üzleti Fôiskola mint szervezet interkulturális érzékenységét mérô és fejlesztését célzó kutatási programjának részeként készült. Az alkalmazott kutatás fó módszertani kihívása az volt, hogy milyen méróeszközt alkalmazzanak a szervezet, illetve az intézményben oktatók interkulturális kompetenciájának mérésére. A cikk áttekinti az interkulturális kompetencia fogalmának alakulását, a méréshez használható eszközök sokaságát, valamint ismerteti az Interkulturális Fejlódési Teszt (Intercultural Development Inventory, IDI) alkalmazásával kapcsolatban publikált tapasztalatokat. A szerzók arra a következtetésre jutnak, hogy az Interkulturális Fejlódési Teszt (IDI) megbízható, és érvényes képet ad az egyének és csoportok interkulturális kompetenciájáról, és ezáltal hasznos eleme lehet a szervezet- és humánerôforrás-fejlesztési intervencióknak.

Kulcsszavak: interkulturális kompetencia, kompetenciamérés, Interkulturális Fejlódési Teszt (Intercultural Development Inventory, IDI)

A tanulmány az IBS Nemzetközi Üzleti Főiskola mint szervezet interkulturális érzékenységét méró és fejlesztését célzó kutatási programjának részeként készült. Az alkalmazott kutatás során az oktatók átlagos interkulturális kompetenciája alapján értékeljük az intézmény interkulturális kompetenciáját. A kutatás tervezett menete szerint elóször egy véletlen rétegzett oktatói minta alapján megmérjük az oktatók interkulturális kompetenciáját, majd egy visszacsatolási megbeszélés, valamint egy képzési program után ismét ugyanazzal az eszközzel mérjük, hogy fejlődött-e vagy sem az oktatók átlagos interkulturális kompetenciája. Az alkalmazott kutatás fó módszertani kihívása a méróeszköz kiválasztása volt, figyelembe véve annak elméleti megalapozottságát, érvényességét, megbízhatóságát, valamint hozzáférhetőségét.

Jelen tanulmány célja, hogy szakmai és módszertani megalapozásként szolgáljon az alkalmazott kutatás során használt módszertanhoz, az interkulturális kompetencia mérésére kiválasztott mérőeszköz megbízhatóságára és érvényességére nézve. A cikk először áttekinti az interkulturális kompetencia fogalmának alakulását, majd elemzi az interkulturális kompetencia méréséhez használható eszközök sokféleségét, végezetül összegzi a kutatáshoz kiválasztott Interkulturális Fejlődési Teszt (Intercultural Development Inventory, IDI) alkalmazásával kapcsolatban publikált tapasztalatokat annak érdekében, hogy megállapítsa, mennyiben alkalmas ez a méróeszköz az IBS Nemzetközi Üzleti Főiskola kutatási céljainak megvalósítására.

\section{Az interkulturális kompetencia fogalma}

$\mathrm{Az}$ interkulturális kompetencia konceptualizációja és mérésének lehetôségei az 1970-es években kerültek a különböző tudományterületek - kommunikáció, pszichológia, nyelvészet, szociológia, oktatás - figyelmének középpontjába. Az interkulturális kompetencia vizsgálata és a felhasználhatónak túnő, elsősorban pszichometrikus méróeszközök ebben a kontextusban való alkalmazása több évtizedig szinte kizárólag az Egyesült Államokban zajlott, fóként a középfokú és 
a felsôoktatásban, illetve kisebb mértékben az üzleti életben. Az elsố tanulmányok a Békehadtest (Peace Corps) önkénteseinek munkájához kapcsolódtak: nemzetközi tapasztalataik fontos inputot jelentettek a kutatók számára, míg a felhasználók az önkéntesek kiválasztásánál és felkészítésénél alkalmazták a formálódó elméleteket.

Berardo (2005: p. 4.) szintetizált definíciója tekinthetô a legáltalánosabban elfogadottnak, bár a benne szereplő fogalmak értelmezése kapcsán jelentôs nézetkülönbségeket figyelhetünk meg: „,Az interkulturális kompetencia az a képesség, mellyel hatékonyan és megfelelően tudunk közremúködni számos interkulturális helyzetben, sikeresen felhasználva saját interkulturális forrásainkat (pl. tudás, képességek és attitúd)."

Chen (1997) különbséget tesz interkulturális kompetencia (intercultural competence, ICC), interkulturális tudatosság (intercultural awareness, ICA) és interkulturális érzékenység (intercultural sensitivity, ICS) között. Chen (1997: p. 4.) Bronfenbener et al. 1958ban megjelent első ICS definícióját idézi, ami szerint ,az embernek az a képessége, hogy tudja, mások viselkedése, percepciói és érzései miként különböznek a sajátjától." Chen (1997) szerint az ICS (attitúd) alapját az interkulturális tudatosság (tudás, ismeretek) képezi, és ez vezet el az interkulturális kompetenciához (viselkedésbeli képességek). Ezt a fajta hármasságot (a kommunikáció kognitív, affektív és viselkedésbeli aspektusait) szinte minden késóbbi modell is megórizte. Chen (1997: p. 5.) interkulturális érzékenység definíciója a következóképpen szól: „Az egyén azon képessége, hogy a kulturális különbségek megértése és tiszteletben tartása pozitív emóciókat váltson ki, ami az interkulturális kommunikációban megfelelő és hatékony viselkedést generál." A pozitív emóció akkor jöhet létre (azaz akkor interkulturálisan érzékeny az egyén), ha rendelkezik az alábbi személyiségjegyekkel és készségekkel: önbecsülés, önmegfigyelés, nyitottság, empátia, interakcióra való odafigyelés és nem ítélkezố attitúd.

Spitzberg és Changnon (2009) az eddig publikált legteljesebb összefoglalását adta az interkulturális kompetencia különböző definícióinak, elméleteinek és modelljeinek. Az ő felosztásukat követve ötféle modellt különböztetünk meg: többelemes (compositional), társas orientációjú (co-orientational), fejlődési (developmental), adaptációs (adaptational) és ok-okozati folyamat (causal process). A szerzók ugyanakkor hozzáteszik, hogy bár az osztályozás elősegíti a tisztánlátást, néhány nagy hatású modell több kategória jellegzetességeit is magán viseli.

\section{Többelemes modellek}

A többelemes modellekben, amelyek a legrégibbek, és ezért a legszámosabbak, a kutatók listát állítottak össze a kompetensnek vélt személyek tulajdonságairól, készségeiről, attitűdjeirôl, de ezen elemek között nem határoztak meg semmilyen kapcsolatot, korrelációt.

Az ICC egyik legrégebbi meghatározását Rubennél (1976, idézi Sinicorpe et al., 2005) találjuk, aki szakítva a korábbi elméletekkel, a középpontba a viselkedést tette, mondván, hiába rendelkezik valaki a kívánatos személyiségjegyekkel és attitűdökkel, a viselkedésével sok esetben mégis kudarcot vall. Szerinte az interkulturális kompetencia azt jelenti, hogy „az ember képes oly módon funkcionálni, hogy az viszonylag összhangban van környezetének igényeivel, képességeivel, céljaival és elvárásaival, és ugyanakkor saját igényeit, képességeit, céljait és elvárásait is kielégíti” (p. 336.). Ruben az interkulturális kompetenciát, azaz a sikeres interkulturális interakciót a következő hét dimenzió mentén definiálta: tisztelet, interakciós hozzáállás, a tudáshoz (tanuláshoz) való hozzáállás, empátia, énközpontú szerepmagatartás, interakció-menedzsment és bizonytalanságtúrés. $\mathrm{Az}$ egyes dimenziókat operacionalizálta is, skálákat dolgozott ki hozzájuk, és ez képezi a még ma is használatos Behavioral Assessment Scale for Intercultural Competence (BASIC) méróeszköz alapját.

Hunter et al. (2004) először az 1988-ban említett globális kompetenciát tanulmányozták, amit az interkulturális kompetenciánál magasabb szintúnek hipotetizáltak. Üzletemberekkel, HR-menedzserekkel, diplomatákkal, interkulturális szakértôkkel és vezető nemzetközi trénerekkel végzett Delphi-megbeszélés alapján a következô definíciót publikálták: „,Az embernek nyitottnak kell lennie, cselekvően meg kell próbálnia megérteni mások kulturális normáit és elvárásait, majd ezt a megszerzett tudást a számára idegen környezetben zajló cselekedetek, kommunikáció és a hatékony munkavégzés során alkalmaznia kell.” (p. 6.) A kvantitatív és kvalitatív kérdő́ives felmérésükben a globális kompetencia elemeit próbálták meghatározni, és ezeket négy csoportba osztották: tudás, képességek, hozzáállás és tapasztalat.

Érdekességként említjük meg, hogy Hunter et al. (2004) kutatása szerint sem idegennyelv-ismeret, sem hosszabb külföldi tartózkodás, de még fóiskolai diploma sem szükséges a globális kompetenciához.

A többelemes modellek közül kiemelésre érdemes Deardorff (2006) interkulturális kompetencia piramisa. Annyiban tér el az egyszerú „listás” modellektốl, hogy meghatározza az elemek hierarchiáját, egymásra épuilését. Az 1. ábrán látható, hogy Chenhez (1997) 
hasonlóan szerinte is az attitúd (érzékenység) képezi a kompetencia alapját, amire a tudás és a készségek épülnek, és ezek együttes hatására nemcsak az interakció lesz eredményes és helyes, hanem az abban részt vevő személy is újfajta képességeket (pl. alkalmazkodóképesség) sajátít el.

Az interkulturális kompetencia piramismodellje (Deardorff, 2006: p. 254.)

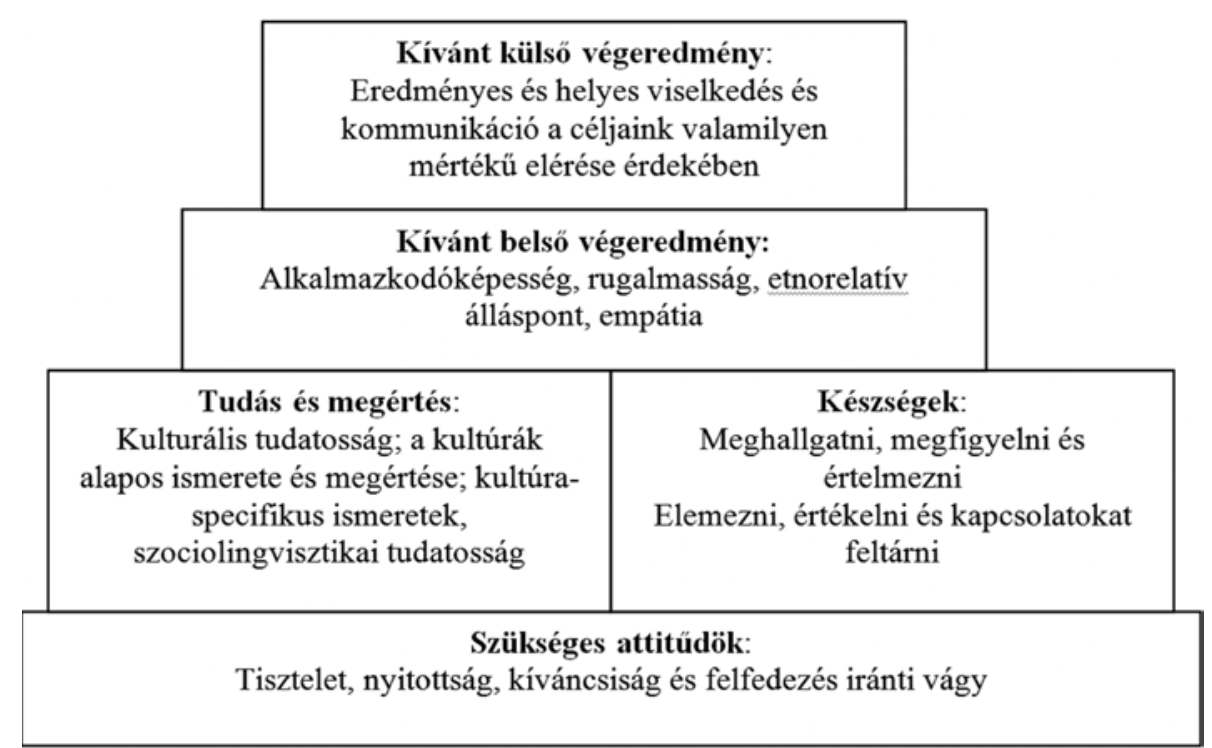

Fantini (2000, 2006) az ICC fogalmának három összetevớjét említi: a kapcsolatok kialakításának és fenntartásának képessége, a hatékony és megfelelő (minimális veszteséggel vagy torzulással járó) kommunikációra való képesség és a közös érdek vagy igény megvalósítását célzó együttmúködési képesség. Ezen interakciós képességek mellett Fantini (2006) a kompetencia öt dimenzióját határozza meg: a már korábban említett tudatosság, attitúd, képességek és ismeretek mellett azonos fontosságot tulajdonít a nyelvismeretnek, mondván: „az interkulturális kompetencia sine qua non-ja, hogy az ember alternatív módokon tudjon érzékelni, fogalmat alkotni és kifejezni magát” (p. 37.), és ennek elsajátításában hasznos eszköz a nyelvtanulás.

\section{Társas orientációjú modellek}

A társas orientációjú modellekben az interkulturális megértés interakciós teljesítményét definiálják, pl. percepciós pontosság, empátia, perspektívaváltás, tehát a kompetencia kommunikatív egymásra utaltságot és közös jelentéstartalmat feltételez. Ezekben a modellekben kiemelt hangsúlyt kap a megértés, a „közös nevező” megtalálása, ami alapját képezi a késóbbi megfelelő és eredményes interakciónak. Fantini (2000) nyelvészeti szempontból közelítve úgy véli, hogy a többelemes modellekben szereplő tényezók valószínúleg megkönnyítik a beszélgetést, és ebben a folyamatban tetten lehet érni a társas orientációt: a felhasznált szimbólumrendszerek (nyelv, jelentéstartalmak, illetve felhasználói normák) egyre nagyobb egyezést mutatnak. A Byram

1. ábra és munkatársai (1997) által kidolgozott többdimenziós interkulturális kompetenciamodell (European Multidimensional Model of ICC) öt részból áll, és abban hasonlít Fantini (2000) definíciójára, hogy a tudatosság, attitüd, készségek, ismeretek (awareness, attitude, skills and knowledge $A+A S K)$ mellé beemeli az interaktív (identitás negociáció) készségeket. Így az interkulturális beszélő két (vagy több) kultúrában egyaránt sikeresen tud negociálni, mivel identitásában nincsenek össze nem egyeztethetố elemek. Spitzberg és Changnon (2009) úgy véli, hogy ezekben a modellekben az interakció résztvevói olyan kulturális légkört, olyan kulturális identitásokat teremtenek meg, amelyek mellett egyik résztvevố sem tölt be uralkodó, illetve alárendelt pozíciót.

\section{Fejlódési modellek}

A társas orientációjú modellek figyelmen kívül hagyják az időtényezôt, pedig ennek minden bizonnyal fontos szerepe van abban, hogy mi is történik egy adott kapcsolatban, illetve interakcióban. A fejlődési modellek középpontjában az áll, hogy az interkulturális kompetencia, illetve érzékenység egy jól szakaszolható fejlődési folyamat, és mint ilyen visszafordíthatatlan. King és Baxter Magolda (2005) az interkulturális érettség kifejlődését tanulmányozta föiskolai hallgatókkal folytatott interjúk alapján. A fejlettség három aspektusának (kognitív, intraperszonális, interperszonális) három szintjét (alapfokú, középfokú és érett) határozták meg. Modelljük fontos eleme, hogy a fejlődés csak önreflexió, tanulás és rendszeres interakció során következik be.

Bennett $(1993,2004)$ elmélete szerint - és ebben egyetért Chennel (1997) - a kompetencia létezéséhez interkulturális érzékenység szükséges. Az érzékenység a kulturális különbség percepciójának összetettségét jelzi, míg a kompetencia azt jelenti, hogy a kulturáli- 
san érzékeny egyén megfelelő és eredményes magatartást tanúsít más kulturális környezetben. Ha valakinél egy adott kultúrában eltöltött idő alatt kialakul az interkulturális érzékenység, akkor azt egy másikban mozgósítani tudja: az érzékenysége révén könnyebben válik kompetenssé az új kontextusban. Bennett eredeti interkulturális érzékenység fejlődési modelljében (Developmental Model of Intercultural Sensitivity) ami a 2. ábrán látható - hat fázist különböztet meg: három etnocentrikus (tagadás, védekezés, minimalizálás) és három etnorelatív orientációt (elfogadás, adaptáció, integráció). Összességében az etnocentrikus fázisokban az ember kerülni próbálja a kulturális különbségeket, míg az etnorelatív fázisokban keresi azokat.

Az interkulturális érzékenység modellje (Hammer - Bennett - Wiseman, 2003: p. 424. alapján)

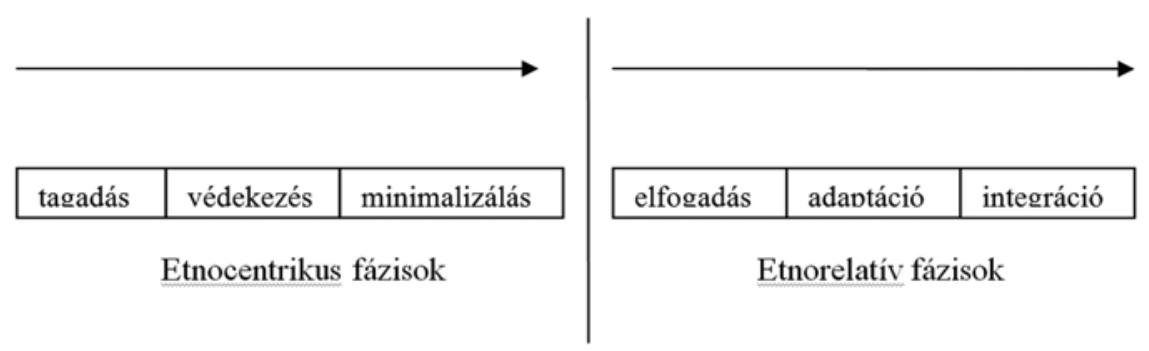

E modellek komoly hiányosságának tartja Spitzberg és Changnon (2009), hogy természetükbőll adódóan nem foglalkoznak azzal, milyen személyiségjegyek, illetve kompetenciák segítik elő (illetve gátolják) az interkulturális érzékenység kialakulását.

\section{Adaptációs modellek}

Az adaptációs modellekben az interakció szereplôi egymásra utaltak, és kölcsönös alkalmazkodás jellemzi óket. Így a kompetencia a más kultúrájúakkal folytatott interakcióban megvalósuló kölcsönös alkalmazkodás. Kim (2001) a következóképpen definiálja az interkulturális adaptációt: „olyan dinamikus folyamat, amelyben az ember, miután új, ismeretlen vagy megváltozott kulturális környezetbe kerül, a környezettel viszonylag stabil, kölcsönös és jól múködő kapcsolatokat alakít ki (illetve újra kialakít) és tart fenn" (p. 31.). Kim hozzáteszi, hogy a környezethez való alkalmazkodás megköveteli az egyén folyamatos kommunikációját, így az alkalmazkodás akár kommunikációs folyamatként is felfogható.

Matsumoto et al. (2001) interkulturális kompetencia, felfogásának középpontjában az asszimiláció, illetve az alkalmazkodás pszichológiája áll, de viszonylag kis hangsúlyt kap az adaptáció kölcsönössége. A szerzók szerint az eredményes interkulturális interakció al- kalmazkodást követel a résztvevóktól, amihez viszont három pszichológiai készség szükséges: a fejlett emóciószabályozás, a nyitottság és rugalmasság, valamint a kritikai gondolkodás. Míg ezek szerepét már korábbi tanulmányok is vizsgálták, Matsumoto et al. (2001) egyetlen, interkulturális alkalmazkodást magyarázó, illetve előrejelző modellbe integrálta az elemeket. Empirikus kutatásukat, aminek eredménye az ICAPS-55 mérốeszköz, célzottan amerikaiak és japánok közötti interakciókra vonatkozóan végezték.

Az adaptáció, és ezzel szemben a saját kultúra megôrzésére való törekvés minden elméleti munkában fontos szerepet kap, de kiváltképpen az adaptációs modellekben. Kim (2001) maga is azt írja, hogy az adaptáció

2. ábra „mindig kompromisszumot jelent”, de az interkulturális kompetencia kifejlődése szempontjából alapvetô fontosságú.

\section{Ok-okozat folyamatmodellek}

$\mathrm{Az}$ ok-okozat folyamatmodellek meghatározott viszonyokat jeleznek az elemek között, tehát meghatározzák azokat a végkifejleteket, amelyek a kompetencia meglétét bizonyítják. Az ilyen modelleket rendszerint olyan kvantitatív jellegú kutatásokhoz hozzák létre, amelyek felhasználásával a kompetencia kialakulásához/meglétéhez szükséges változót kívánják feltárni. Griffith és Harvey (2000) szerint például a kulturális interakció és a kommunikációs interakció közvetlen befolyásolásán keresztül a kulturális megértés és a kommunikatív kompetencia egymásra is ható képességei indirekten meghatározzák a kapcsolat minőségét. Spitzberg és Changnon (2008) idesorolja Hammer et al. (1998) elméleti keretét, illetve kutatását, miszerint az egymáshoz vonzódó és egymással bensőséges viszonyban lévő emberek jobban bíznak abban, hogy megértik a másikat, ami csökkenti az aggodalmukat és erôsíti az interakcióval való elégedettségüket. A szerzók azt a kifogást emelik az ok-okozati modellekkel szemben, hogy a legtöbbjükben túl sok a kétirányú nyíl, így - noha a hagyományos értelemben vett tudományos magyarázatot kínálnak - nem könnyú a hipotézisek igazolása, illetve elvetése.

A szakirodalom szinte mindegyik interkulturális kompetenciamodellel kapcsolatban három fố aggályt fogalmaz meg. Számos tanulmány (Deardorff, 2006; Spitzberg - Changnon, 2009; Holmes - O'Neill, 2012) hívja fel a figyelmet a konceptualizációk etnocentrikus (nyugati nézőpontbeli) mivoltára. Csak a további nem- 
nyugati és nemamerikai kutatások fogják majd eldönteni, hogy a jelenlegi definíciók és elméletek mennyiben általánosíthatók a keleti kultúrákra. Holmes és O’Neill (2012) új tanulmánya, amiben a kutatók új-zélandi egyetemi hallgatókat vizsgáltak etnográfiai módszerrel, figyelemre méltó eltérést talált a kínai és az angolszász diákok interakció-kezelése között.

A kételyek második csoportja azt illeti, hogy kevés kutatás foglalkozott azzal, hogy pszichésen és emocionálisan mi is történik az egyénben, mi a szerepe a gondolkodási folyamatoknak, az introspekciónak, önreflexiónak és az interakciók értelmezésének.

Végezetül még az adaptációs modellek sem foglalkoztak kellő mélységben az alkalmazkodás pontos meghatározásával, illetve operacionalizálásával. Milyen mértékú alkalmazkodás a kívánatos, ami még nem jelenti az egyéni identitás feladását? Kinek kell alkalmazkodnia kihez? Az alkalmazkodási kényszer nem hat-e károsan az interakció többi jellegzetességére? Ráadásul, Spitzberg és Changnon (2009) szerint az alkalmazkodókészség bizonyosan nem állandó személyiségjegy, hanem a kontextustól függóen változik.

Szervezetünk magyarországi székhelyú, szolgáltatáscentrikus felsốoktatási intézmény, amelybe a hallgatók mintegy nyolcvan országból érkeznek. A nemzetközi oktatói gárdának, a kettős diplomából adódóan, egyaránt meg kell felelnie a magyar akkreditációs követelményeknek és a partnerintézmény által közvetített brit felsôoktatási standardoknak. A fenti tényezôk alapos elemzése után arra a következtetésre jutottunk, hogy az interkulturális érzékenység bennetti modellje illeszkedik leginkább azokhoz az elvárásokhoz, amelyeket a foóiskola vezetése és a hallgatók támasztanak a tanári karral szemben. Ezekról bóvebben a program eredményeit ismertetố tanulmányunkban szándékozunk írni.

\section{Magyarországi kutatások}

A téma hazai kutatásainak döntô hányada a nyelvoktatáshoz kapcsolódik, és mint ilyen, arra fókuszál, hogy a nyelvoktatás során miként lehet a tanulók interkulturális kompetenciáját kialakítani, illetve fejleszteni.

Lakatosné és Dorner (2007), Byram, Gribkova és Starkey (2002) idegennyelv-tanároknak szóló ajánlásai alapján az európai testvériskolák programban részt vevô pedagógusok számára az ismeret, a készségek és az attitúdök hármasságát határozzák meg elvárásként, de ezeket nem a direkt interkulturális interakciók szempontjából tartják fontosnak, hanem a középfokú oktatásban. Ugyanezt a modellt alkalmazza Piros (2006) a magyar mint idegen nyelv oktatására, és tanulmányában olyan típusfeladatokat ismertet, amelyek felhasználásával fejleszthető a tanulók interkulturális kompetenciája. Bíró (2007), ugyancsak nyelvoktatási kontextusban Bennett modelljét ismerteti.

Az interkulturális kompetencia vizsgálatának és fejlesztésének egyik legfontosabb hazai bázisa az Artemisszió Alapítvány, ami különböző európai uniós projektek keretében elsôsorban tanároknak és migránsokkal dolgozó szociális munkásoknak szóló képzési projekteket dolgoz ki. Elméleti szempontból kiemelkedik Várhegyi (é. n.) tanulmánya, valamint Várhegyi és Nann (é. n.) kutatási beszámolója a százharmincöt fôs nemzetközi mintán végzett interjús vizsgálatukról.

Koltai (2009a, 2009b) gyakorló vállalati vezetóként a külföldi kiküldetésekkel összefüggésben vizsgálja az interkulturális kompetencia elemeit és mérésének lehetőségét. Részletesen beszámol arról a projektről, amelyben egy, a vállalata számára kifejlesztett értékelő központtal (assessment centre, AC) harminchét potenciális kiküldött interkulturális kompetenciáját mérték, és értékelték.

\section{Méröeszközök az interkulturális kompetencia mérésére}

Paige (2004: p. 86) következő definícióját használjuk: „Az interkulturális instrumentum olyan mérési eszköz, ami meghatározza, leírja, felméri, kategorizálja, illetve értékeli az egyének, csoportok és szervezetek kulturális sajátosságait." Ily módon idetartozik számos olyan pszichológiai és interkulturális pszichológiai teszt is, amelyeket eredetileg nem erre a célra fejlesztettek ki, pl. a Myers-Briggs típusindikátor. Fantini (2006) listája pontosan hetven eszközt sorol fel, de nem tartalmaz több olyan belsô, szervezeten belül használatos eszközt, amelyeket a szerzók ismernek. Fontos megemlíteni, hogy egy pár kivételtól eltekintve az instrumentumokat az Egyesült Államokban (illetve angolszász nyelvterületen) fejlesztették ki, és közülük csak nagyon keveset alkalmaztak, illetve vizsgáltak más kulturális környezetben (Fritz é. n.; Simons - Krols, 2010; www.incaproject.org). A mérési eszközök más kulturális környezetben való alkalmazását elsősorban az nehezíti meg, hogy nem állnak rendelkezésre megbízható fordítások.

\section{A mérés tárgya}

Bennett (2004) a kulturális méréseknek három szintjét különbözteti meg: a) a kulturális szint, b) az interkulturális szint és c) az interkulturális élmény szintje.

Az elsố megfelel a több modellben szereplő ismereti komponensnek. Az ilyen instrumentumok a Hall, Hofstede, Trompenaars és mások által kidolgozott ér- 
tékdimenziók alapján írják le, illetve hasonlítják össze a kultúrákat. A gyakorlatban a kulturális értékorientációk méréséből sokan következtetnek a vizsgált személyek interkulturális kompetenciájára is, ám a kettő nem feltétlenül korrelál: lehet valaki kompetens ismeretek nélkül, illetve az ismeretek birtoklása nem garantálja a kompetenciát (attól, hogy valaki tudja, hogy „kollektivista", nem fog feltétlenül megfelelóen és eredményesen kommunikálni más orientációjú személyekkel). Ez a mérési szint az ismereti elemen túl fontos az önismeret (és ezáltal az önfejlesztés) szempontjából is.

A második szinten a kultúrák elemzése és összehasonlítása után a figyelem a kultúrák közötti interakcióra helyeződik át. Az interkulturális pszichológia modelljeire és eredményeire építő mérés arra alapoz, hogy bizonyos pszichológiai változók (személyiségjegyek, affektív állapotok, magatartások) korrelálnak bizonyos végkifejletekkel, és a kettő ok-okozati viszonyban van. Bennett (2004) Brislin szóbeli közlését idézi, miszerint semmi okunk azt feltételezni, hogy - példának okáért - a Myers-Briggs-féle személyiségteszt a világon mindenütt érvényes lenne, vagy az eredményból következtetni lehetne a kulturális adaptációra, pedig gyakran használják erre a célra. Idetartoznak a kritériumorientált instrumentumok, amelyek olyan, más kutatásokban feltárt jellemzóket mérnek, amelyeket az interkulturális eredményességgel lehet összekapcsolni (pl. a CCAI). Mint minden pszichometrikus tesztnél a kérdés az, hogyan definiáljuk az interkulturális kompetenciát, és milyen indikátorokat használunk a mérésére. A korreláció sok esetben valószínúsíthetô, de valószínúleg egyik sem jelent tökéletes megoldást.

$\mathrm{Az}$ interkulturális élmény mérési szintjét azért javasolja Bennett (2004), mert szerinte a hagyományos pszichológia pozitivista és lineáris ok-okozati összefüggéseket keres, következésképpen nem képes megmagyarázni a komplexebb csoportjelenségeket. Ennek fényében dolgozta ki Bennett, elsősorban George Kelly amerikai pszichológus kognitív konstruktivizmus elméletére építve az érzékenységfejlődési modelljét (DMIS) (részletesen 1 . fentebb). A modell szerint az interkulturális kompetencia megléte azon áll vagy bukik, hogy az ember képes-e alternatív kulturális élményeket konstruálni. Azok az emberek, akik döntóen egyetlen kultúrában szocializálódtak (monokulturálisak), képtelenek megtapasztalni a saját és a más kultúrájúak percepciója közti különbséget. Bennett modellje azt a fejlődést írja le, ahogy az ember elsajátítja az alternatív élmények megteremtésének képességét, és az erre alapuló, paraméteres kvantitatív vizsgálati eszköz, az Interkulturális Fejlettségi Teszt (IDI) azt becsüli meg, hogy a vizsgált személy melyik fejlettségi fázisban van.

\section{A mérốeszközök}

A legtöbb instrumentum indirekt, azaz bizonyos készségek, magatartások, attitúdök és tulajdonságok meglétéből vagy meg nem létéből következtet az interkulturális kompetencia fokára. Az ICAPS-55 és a CCAI az egyén különböző kontextusokban mutatott alkalmazkodókészségét becsüli meg, de a rugalmasság és a nyitottság kivételével egymástól eltéró indikátorokból von le következtetéseket.

A kettő közül a gyakran használt Cross-cultural Adaptability Inventory (CCAI) az 1990-es évek elején jelent meg. Kelley és Meyers több tanulmányt is közreadott az instrumentumról, de kevés információ áll rendelkezésre a mögöttes elméletról, illetve a modell kidolgozásáról. Williams (2005) idézi a szerzóket, miszerint a CCAI olyan „képzési instrumentum, amely megmondja az egyénnek, hogy mekkora esélye van az interkulturális eredményességre". A CCAI négy dimenziót mér: érzelmi ellenállás, rugalmasság és nyitottság, perceptuális pontosság és személyes autonómia. Sinicrope, Norris és Watanabe (2007) több, a CCAI-t alkalmazó kutatást ismertet, amelyek érvényesség és megbízhatóság szempontjából vegyes eredményeket mutatnak. Ugyancsak ók idézik Davis és Finneyt (2006), akik a CCAI érvényességét vizsgálták faktoranalízis segítségével. Az eszköz megbízhatósága az egyes dimenziók szerint eltérő, de elfogadható mértékú volt, viszont szignifikáns korreláció mutatkozott az egyes dimenziók között. Davis és Finney (2006) ezért továbbfejlesztéséig nem javasolja az eszköz használatát.

Az IDI, amirôl a késóbbiekben bővebben írunk, az interkulturális érzékenység fejlettségi modelljébe helyezi el a teszt kitöltójét. A YOGA a kettốt egyszerre próbálja meg: egyrészt mér bizonyos ICC-kompetenciákat, másrészt következtet a tapasztalati fejlettségi fázisra.

$\mathrm{Az}$ eszközök jelentős része meghatározott kontextusokban való felhasználásra készült, pl. Teacher Multicultural Attitude Survey (Ponterotton - Baluch Grieg - Rivera, 1998), vagy az Intercultural Sensitivity Inventory (ICSI) (Bhawuk - Brislin, 1992), ami eredetileg az individualista USA és a kollektivista Japán közötti üzleti szférában való magatartási alkalmazkodást méri.

Bár a 2000 utáni kutatások zömében két üzleti forgalomban megvásárolható instrumentum, a CCAI és az IDI szerepel, léteznek figyelemre méltó, helyi célokra kifejlesztett eszközök. Olson és Kroeger (2001) fejlesztése, az Intercultural Sensitivity Index (ISI) a Bennettféle interkulturális érzékenységi skála hat szakaszát használja, de emellé beemelik a globális kompetencia három dimenzióját (tárgyi tudás, perceptuális megértés, interkulturális kommunikáció). Az előtesztelésben 
a kutatók New Jersey City Egyetemen tanító kollégái vettek részt, és ezzel magyarázták, hogy az alanyok döntô többsége az etnorelatív fázisokba sorolta magát. Williams (2005) vizsgálatában külföldi tanulmányútra induló, illetve helyben maradó egyetemi hallgatókat tesztelt egy szemeszter elején és a végén az ISI és a CCAI segítségével. Bár az eredmények kimutatták, hogy a félévet külföldön töltók 11,28 pontos emelkedést mutattak a 192 pontos skálán, maga Williams is az eredmények óvatos kezelésére hívta fel a figyelmet.

Az Assessment of Intercultural Competence (AIC) instrumentumot a Federation of the Experiment in International Living programjainak értékelésére fejlesztette ki Fantini (2000, 2006) kutatócsoportja. Fantini interkulturális kompetencia fogalommeghatározását felhasználva az instrumentum - újszerú módon - nemcsak önértékelésre alapul, hanem az alanyok környezetének véleményét is figyelembe veszi a kompetencia szintjének értékelésében.

A direkt mérés viszonylag kevéssé elterjedt, elsősorban az adatgyuujtés és -elemzés időigényes és bonyolult módja miatt, pedig az így gyújjtött adatok révén kiküszöbölhetố az önkitöltôs, illetve az indirekt módszereknél felmerülő adatminőségi problémák jó része. A direkt mérésnél háromféle megközelítést találunk: teljesítményértékelés (valós idejú szituációkban tanúsított magatartás) (pl. Byram, 1997), portfólióértékelés (reflexív vagy egyéb jellegú írásmúvek) (pl. Byram, 1997) és interjú (pl. Fantini, 2006). Korábban Kim (1992) óva intett attól, hogy az interkulturális kompetenciát konkrét teljesítmény/output alapján mérjük, mivel ilyen esetekben a kompetenciát „,kontextuális és kapcsolati feltételek bonyolítják, és ezért nem fogalmazható meg az interkulturális kommunikációs kompetencia olyan definíciója, ami az interkulturális találkozás többféle típusában és szituációjában állandó. A kompetenciát az jelenti, hogy a személy összességében mennyire képes az eltérô kulturális háttérrel rendelkezőkkel kommunikálni." (p. 372.) Ugyanezt az ellenérvet fogalmazza meg Holmes és O'Neill (2012), akik az interkulturális kompetencia mellett a kapcsolatiság (relationality) szerepét emelték ki.

Végezetül találunk néhány példát az indirekt és a direkt mérés kombinálására is, melyek közül érdemes megemlíteni Fantini (2006) munkáját és az INCA (Intercultural Competence Assessment) projektet, mely utóbbi a kevés európai kezdeményezés egyike ezen a téren. Az INCA (www.incaproject.org) háromféle eszközt kombinál (önkitöltős kérdőív, szöveges vagy videó szituációkra való reflexió és szerepjáték) a kompetencia hat dimenziójának (bizonytalanságtúrés, magatartásbeli rugalmasság, kommunikációs tudatosság, ismeretfelfedezés, másság tisztelete, empátia) mérésére. Sajnálatos módon az INCA kapcsán nem találtunk megbízható publikációt, csak a webhelyen érhetőek el a kutatással kapcsolatos eszközök.

A Függelékben szereplő 1. táblázatban összefoglaltuk a leggyakrabban használatos instrumentumok fớbb paramétereit.

\section{A mérés nehézségei}

A mérési eszközökkel kapcsolatos problémákat, aggályokat, korlátokat a szerzók többnyire két nagyobb csoportba sorolják. Az első fejezetból kiderült, milyen sokféle értelmezése van az interkulturális kompetenciának, és ez a fajta fogalmi tisztázatlanság - bár önmagában nem probléma - megnehezíti a potenciális felhasználók (tanárok, trénerek, HR-menedzserek) dolgát. Ráadásul kevés instrumentumról áll rendelkezésre annak fogalmi és külső érvényességét, illetve megbízhatóságát tárgyaló tanulmány. Sok esetben nem deríthetố ki pontosan, hogy milyen elméleti háttérből indultak ki az instrumentum készítői, hogyan állították össze, illetve milyen és mekkora sokaságon próbálták ki, márpedig ennek hiányában sem a felhasználó, sem a teszt alanya nem tudja értelmezni a kapott eredményeket.

$\mathrm{Az}$ indirekt önkitöltős kérdő́ívekkel kapcsolatban szúnni nem akaró kételyeiket hangoztatják a kutatók (Altshuler et al., 2003; Arasaratnam - Doerfel, 2005; Hammer et al., 2003; Williams, 2005). A probléma nem feltétlenül az, hogy az alanyok meg akarják szépíteni tulajdonságaikat, attitúdjeiket, hanem az, hogy nem tudják felmérni, milyen magatartást tanúsítanának egy-egy feltételezett interkulturális találkozásban. Ez elsôsorban a különféle intervenciók (külföldi tanulás, tréning) elő́tti méréseknél okoz gondot, mert a posztintervenciós eredmény értékeléskor ezt veszik viszonyítási pontnak.

Mivel az instrumentumok java része önkitöltős, a fogalom természetéból adódóan komoly szerepet kaphat a társadalmi kívánatosság. Ennek kompenzálására több instrumentum tartalmazza a Marlowe-Crown-féle Társadalmi Kívánatosság Skálát, illetve ennek bizonyos elemeit. Az ICSI például az eredeti skála 33 eleméból 11 itemet tartalmaz az összesen 82-ból. Bhawuk és Brislin (1992) azt feltételezte, hogy ha az alanyok ezen 11 itemen magas pontszámot érnek el, akkor a többi 71-en is a kívánatos magatartást tanúsítják. Az IDI-ben nem szerepelnek ezek az itemek, de Paige et al. (2003) fent ismertetett vizsgálata cáfolja, hogy az IDI-eredményekben jelentôs szerepe lenne a társadalmi kívánatosságnak.

Byram (2003) részletesen ír az attitúdök és értékek mérésének technikai és morális gondjairól. Különösen igaz lehet ez akkor, amikor az interkulturális instrumentumot például munkahelyi kiválasztásra használják. 


\section{Interkulturális Fejlettségi Teszt (IDI)}

Az IDI Bennett (1993, 2004) korábban ismertetett interkulturális érzékenységi elméletére épül. Az elsô változatát 1998-ban, a másodikat 2003-ban fejlesztették ki. A folyamatos vizsgálatok és elemzések tükrében tovább módosították, így 2010 óta a harmadik verzió érhetố el (Hammer, 2011).

Az IDI az érvényességi vizsgálatok alapján változtatta Bennett modelljét. Egymás mellé sorolta a tagadást és a védekezést, és bevezette a visszafordulást, a védekezés egy olyan változatát, amikor az ember a sajátjához képest a másik kultúrát tartja magasabb rendúnek, és abból a szempontból védekezés, hogy fenntartja a „mi” és „ók” polarizációt. Az újabb szakirodalomban Hammer (2011) már a polarizáció terminust használja a védekezés és a visszafordulás összefoglalására. A skála másik oldalán összevonja az elfogadás és az adaptáció fázisait, míg az integráció helyett a „kulturális marginalitás” (Bennett, 1993a) fogalmát vezeti be. A marginalitás azt jelenti, hogy az egyén két vagy több kultúra margóján érzi az identitását úgy, hogy egyik sincs a középpontban. A marginalitás két formája a kapszulált, amikor a kultúrától való eltávolodást elidegenülésként éli meg az illető, és a konstruktív, amikor is a kultúrák közötti mozgás szükséges és pozitív része az életének. A XXI. században egyre többen élnek ebben a fázisban, például a nemzetiségi kisebbségek vagy a tartósan külföldön munkát vállalók. Az IDI harmadik verziójában a marginalitás helyett Hammer (2011) a kulturális eltávolodás fogalmát használja, amiben a hangsúly a primer szocializáció terepét jelentő kultúrától való eltávolodást jelenti, mivel az érvényességi vizsgálatok ellentmondtak a marginalitással kapcsolatos korábbi feltételezésnek.

Az IDI hátránya Bennett (2009) szerint, hogy elsősorban csoportok interkulturális érzékenységének mérésére alkalmas, tehát alapvetően nomotetikus, a csoporton belül nem pontosan méri az egyéni eltéréseket: túlbecsüli a „,normatív” állapotot - a minimalizálást és alulbecsüli a skálán ettôl jobbra és balra levố fázisokat. Ezért azt tanácsolja, hogy csoportok esetén az IDI mellett más, kvalitatív jellegú adatgyújtést kell végezni. Hammer (2011) visszautasítja ezt a megalapozatlan állítást, mondván: a három validációs minta (összesen 10.000 alany) bizonyítja az IDI fejlődési orientációs pontszámának normál eloszlását, tehát az IDI egyaránt alkalmas egyéni és csoportszintú elemzésre.

Az IDI-vel mint az interkulturális kompetencia mérőeszközével, alkalmazási lehetôségeivel számos tudományos publikáció foglalkozott az elmúlt években.

A Minnesota Egyetem kutatói, R. Michael Paige, Melody Jacobs-Cassuto, Yelena A. Yershova és Joan
DeJaeghere (2003) az IDI empirikus analíziséról szóló tanulmányukban az IDI-t megbízható méróeszköznek találták, amely megfelelően méri az interkulturális érzékenység fejlődési modelljét. Az IDI megbízhatóságának és érvényességének vizsgálata céljából a szerzők 1998 májusa és 1999 januárja között egy több mint 350 fős, idegen nyelveket (francia, német, portugál, spanyol) különbözố nyelvi szinteken tanuló egyesült államokbeli középiskolai és fóiskolai hallgatókat magában foglaló csoporttal dolgoztak együtt. A résztvevốket kétszer mérték különbözô módszerekkel: minden résztvevốt az IDI-teszt mellett egy, a szerzók által készített demográfiai kérdőívvel és a fóiskolai hallgatókat ezek mellett a Marlowe-Crown-féle „társadalmi kívánatosság" indexszel is. Az adatok elemzése révén a szerzók elemezték az IDI pszichometriai jellemzóit, egyéni súlyozott átlagot számítottak a válaszadók mérésére és összehasonlították az IDI-elemeket a „társadalmi kívánatosság” teszt során kapott válaszokkal. A szerzók az adatok elemzése eredményeképpen arra a következtetésre jutottak, hogy az IDI megbízhatóan méri az interkulturális érzékenységet, de - mint minden olyan eszköz, amely a multidimenzionális emberi kvalitásokat méri - további finomításai szükségesek a jövőben.

Altschuler, Kachur és Sussman (2003) cikke egy New York-i oktatókórházban végzett vizsgálatot ismertet, amely során 26 másodéves rezidens orvos interkulturális érzékenységét mérték 2000-2001-ben. A vizsgálat során a rezidenseket három csoportba osztották és a csoportok különbözó időpontokban és sorrendben vettek részt interkulturális workshopon, IDI-teszten és egy többlépcsôs, orvosoktató jelenlétében történő fiktív beteggel való találkozásokat magában foglaló vizsgán. A vizsgálat eredményei között megemlítendő a demográfiai tényező́k hatása az IDI-teszt eredményeire. A szerzók a résztvevốk alacsony számára és a téma komplex jellegére vezetik vissza azt a tényt, hogy az IDI-eredmények nem mutattak jelentôs változást az interkulturális workshop után, illetve azt, hogy egyes IDI-eredmények nem tükröződtek a többlépcsős orvosi vizsga eredményein. A szerzók konklúziója, hogy az interkulturális érzékenység komplex jelenség, amely nem változtatható meg egy gyors tréninggel, viszont az IDI alkalmas kulturális kompetenciatréningprogramok kialakítására és értékelésére.

A fenti konklúziót támasztja alá DeJaeghere és Cao (2009), a Minnesota Egyetem kutatóinak cikke is. Egy középnyugati iskolai körzetben 86 általános iskolai tanár interkulturális kompetenciájának változásait vizsgálták 2003 és 2008 között úgy, hogy a tanárok egy többéves interkulturális tréning- és workshopsorozaton vettek részt. A résztvevők a tréning- és 
workshop-sorozat előtt és után írták meg az IDI-tesztet. Az eredmények jelentős változást mutatnak: a résztvevôk nézete az etnorelatív irányba mozdult el. A szerzők szerint egy, a DMIS-t figyelembe vevô és az IDI-t mérôeszközként használó komplex szakmai továbbképző és értékelő program kialakítása és bevezetése előnyös minden oktatási intézmény számára, ahol az oktatók és a diákok is eltérô kulturális háttérrel rendelkeznek.

Az IDI használata az egyesült államokbeli felsôoktatási intézményekben is fokozatosan teret nyer. Egy, az ún. community college-ok nemzetköziesedésével foglalkozó tanulmánykötet külön fejezetet szentelt a témának. A fejezet szerzői, Holly A. Emert és Diane L. Pearson (2007) a felsőoktatás nemzetköziesedésének leírása során kitérnek annak interkulturális aspektusára, a hallgatók interkulturális tudására és készségére mint kívánatos kimenetre. Példaértékú esettanulmányként a Minnesota állambeli állami főiskolák és egyetemek „Oktatás a globális tanulásért” elnevezésű konzorciumának (Education for Global Learning / EGL/: A Consortium of Minnesota State Colleges and Universities) tevékenységét elemzik. Az 1995-ben alakult EGL nemzetköziesedési stratégiájának fó komponense a nemzetközi mobilitás, elsôsorban az amerikai hallgatók számára féléves külföldi tanulási lehetôség biztosítása: tíz év alatt mintegy 450 hallgató vett részt a programban, amelynek hatékonysága méréséhez 2003ban az IDI-t választották a hallgatói interkulturális érzékenység eszközének. 2003 és 2005 között 43 hallgató Angliában, 2004 és 2006 között 88 hallgató pedig Costa Ricában töltött egy-egy szemesztert. Az utazást megelőző kötelező orientáció részeként a hallgatók megismerték és megírták az IDI-tesztet. A vendégszemeszter utáni mérés átlagos eredménye egy kisebb csökkenés volt az etnocentrikus hozzáállásban. E pozitív eredmények hatására az EGL vezetősége a hallgatók és oktatók interkulturális kompetenciájának fejlesztését határozta el tantervi és továbbképzési változtatások révén.

Ugyancsak az IDI használatáról számol be egy kaliforniai egyetem hallgatóinak interkulturális kompetenciamérése kapcsán Sample (2009). A nemzetközi tanulmányok szakon az egyik kimeneti cél a külföldi tartózkodás, és ennek révén az interkulturális kompetencia fejlesztése annak érdekében, hogy a végzett hallgatók karrierjük során a világ bármely pontján sikeresen megállják a helyüket. A hallgatók megírják az IDI-tesztet az elsô félévben, majd az interdiszciplináris tanterv mellett (amely tartalmaz politikatudományi, közgazdasági, antropológiai elemeket, gyakran egyetlen komplex tantárgyon belül, amelyet közösen oktat több, különböző tudományághoz tartozó oktató) a szak részét képezô, legalább egy féléves külföldi tanulást megelőzően és azt követően is vannak kurzusaik a kulturális adaptálódás témakörében. E kurzusok mind általános kulturális elemekkel, mind pedig a fogadó országhoz kapcsolódó specifikus témákkal foglalkoznak. Visszatértük után - ez általában a harmadik év második fele vagy a negyedik év - ismételten megírják az IDI-tesztet. A szerző és kollégái ötvenhárom hallgató eredményeit vizsgálták meg, akik 2007-től kezdődően tanultak az adott szakon. Átlagban a vizsgált hallgatók az igen kimagasló, 19,78 ponttal magasabb eredményt értek el a második teszt során.

Érdekesség, hogy a korábbi kanadai diplomata, Joe Greenholtz professzor már 2000-ben, az európai felsôoktatással foglalkozó szakfolyóiratban felhívta a figyelmet a nemzetköziesedő felsôoktatással kapcsolatban az interkulturális érzékenység és kompetencia fontosságára, valamint ezek objektív mérésére. Az interkulturális érzékenység és kompetencia komplex megközelítésére a Bennett-féle DMIS-t, mérésére pedig az IDI-t javasolta, amelyet három területen is felhasználhatónak tart:

- nemzetköziesedô felsôoktatási programok oktatói, kutatói és adminisztratív-vezetôi személyzete szempontjából az IDI-t mind a felvétel, mind az előléptetés és jutalmazás vonatkozásában, továbbá a továbbképzés során is használhatónak tartja,

- szak- és intézményi szintú minőségbiztosítás területén ugyancsak hasznos eszköznek tekinti az IDI-t, végezetül

- a hallgatói szolgáltatások terén a leendő hallgatók felvételiztetésekor és a felvettek teljesítményének mérésére is alkalmasnak tartja.

\section{Összefoglalás és következtetések}

Szakirodalmi áttekintésünk világossá tette, hogy az elmúlt két-három évtizedben - elsôsorban az Egyesült Államokban - fokozott figyelem övezi az interkulturális kompetencia fogalmát, illetve mérésének lehetôségeit. A figyelem indokolt, hiszen társadalmi-gazdasági és egyéni szinten óriási szükség van arra, hogy minél több ember képes legyen „,megfelelően és hatékonyan” kommunikálni más kulturális háttérrel rendelkezókkel.

Láthattuk, hogy az elméleti kutatások elsôsorban a kompetencia modellezését célozzák, és ezzel párhuzamosan nagyszabású és fontos empirikus vizsgálatok is zajlanak. Ezen a téren kiváltképpen fontosnak tartjuk az elméleti és a gyakorlati kutatások egymásra hatását: az interkulturális kompetencia fogalmát illető tisztázás elősegíti az empirikus vizsgálatokat, amelyek ugyanakkor visszahatnak a konceptualizációra. Végsô so- 
ron azonban - lévén az interkulturális kommunikáció alkalmazott tudományág - azt a célt kell magunk elé tûzni, hogy a kutatások alapján megtaláljuk azokat az eszközöket, amelyekkel - akár egyéni, akár csoportos formában - fejleszthetố a kompetencia.

Kérdés, hogy egy instrumentum által mért eredmény mennyire pontos képet adhat az egyén kompetenciájáról, hiszen abban általában egyetértés van, hogy az interkulturális kompetencia több elemből áll. Könnyen elófordulhat tehát, hogy valaki bizonyos téren jobb vagy kevésbé jó, de összességében nehezen mondható ki, hogy kompetens vagy sem. Éppen ezért nagyon óvatosan kell bánni az eszközök használatával, illetve az eredményekból való következtetéssel, tehát az egyetlen eszközzel való mérés prediktív ereje megkérdójelezhetố arra nézve, hogy mennyire lesz valaki sikeres az interkulturális interakcióban.

Az viszont kétségtelen, hogy a mérés fontos eszköz lehet maguk a vizsgálatban részt vevố egyének, valamint az interkulturális kommunikációra és menedzsmentre szakosodott trénerek számára. Az elóbbiek megismerhetik saját erősségeiket és gyengeségeiket, fogalmi keretet kapnak a témával kapcsolatos gondolkodáshoz és cselekvéshez, míg utóbbiak az eredmények tükrében tervezhetik meg a tréningek tartalmát.

Berardo (2005: p. 19.) a következôt írja:

„,...ha a tegnap kihívása az volt, hogy kiválogassuk az interkulturálisan kvalifikált dolgozókat, akkor a ma kihívása az, hogy tömegesen fejlesszük a munkaerốt arra, hogy megfelelóen és hatékonyan dolgozzanak interkulturális környezetben. Ehhez az erófeszítéshez inkább az interkulturális kompetencia fejlesztésére, semmint a definíciójára van szükség."

Tudatosan fejleszteni viszont csak akkor tudunk, ha tudjuk, mit kell fejlesztenünk. Ehhez adnak támpontot az interkulturális kompetencia modelljei és a rájuk épülő méróeszközök. A XXI. század eleji gazdasági környezetben az is fontos, hogy a fejlesztés minél célzottabb, minél költséghatékonyabb legyen, tehát a trénereknek az elméleti háttér ismeretében, a minél pontosabban felmért szükségletek és igények alapján kell kiválasztaniuk azokat az eszközöket és tevékenységeket, amelyek az idevonatkozó tapasztalatok alapján garantálják az interkulturális kompetencia fejlődését. A szervezetünk belsố és külső körülményeinek és lehetőségeinek figyelembevétele, valamint a szakirodalom tanulmányozása alapján jutottunk arra a következtetésre, hogy az IBS oktatóinak interkulturális érzékenységét az IDI felhasználásával mérjük, illetve fejlesztjük. A projekt további fázisait egy másik tanulmányban kívánjuk ismertetni.

\section{Felhasznált irodalom}

Altshuler, L. - Sussman, N.M. - Kachur, E. (2003): Assessing changes in intercultural sensitivity among physician trainees using the Intercultural Development Inventory. International Journal of Intercultural Relations, 27: p. 387-401.

Bennett, J.M. (1993a): Cultural marginality: identity issues in intercultural training. in: Paige, R.M. (ed.): Education for the intercultural experience. Yarmouth: Intercultural Press: p. 109-136.

Bennett, M.J. (1986): Towards ethnorelativism: a developmental model of intercultural sensitivity. in: Paige, R.M. (ed.): Cross-cultural orientation: New conceptualizations and applications. New York: University Press of America: p. 27-70.

Bennett, M.J. (1993b): Toward ethnorelativism: a developmental model of intercultural sensitivity. In: Paige, M.R. (ed.) Education for the Intercultural Experience. 2nd ed. Yarmouth: Intercultural Press: p. 21-72.

Bennett, M.J. (2009): Defining, measuring and facilitating intercultural learning: a conceptual introduction the Intercultural Education double supplement. Intercultural Education, 30(S1-2): p. S1-13.

Berardo, K. (2005): Intercultural competence: A synthesis and discussion of current research and theories. An Area Studies Project. University of Luton. Elérhetőség: http:// www.diversophy.com/ic_comp/LinkedDocuments/ ICCompetence-Berardo.pdf (Letölt.: 2012. aug. 25.)

Bíró E. (2007): Az interkulturális kompetencia fejlesztésének csapdái. Iskolakultúra, 8-10: p. 70-77.

Byram, M. (1997): Teaching and assessing intercultural communicative competence. Philadelphia: Multilingual Matters

Chen, G.-M. (1997): A review of the concept of intercultural sensitivity. A Pacific and Asian Communication Association kongresszusán elhangzott eladás. Honolulu, 1997. január. (Online) Elérhetőség: www.eric.com (Letöltés: 2012. június 18.)

Deardorff, D.K. (2004): The identification and assessment of intercultural competence as a student outcome of internationalization at institutions of higher education in the United States. Ph.D. disszertáció. North Carolina State University. (Online) Elérhetôség: http://repository. lib.ncsu.edu/ir/bitstream/1840.16/5733/1/etd.pdf. (Letöltés: 2012. augusztus 27.)

DeJaeghere, J. - Cao, Y. (2009): U.S. teachers' intercultural competence: does professional development matter? International Journal of Intercultural Re lations, 33: p. 437-447.

Emert, H.A. - Pearson, D.L. (2007): Expanding the vision of international education: collaboration, assessment, and intercultural development. New Directions for Community Colleges, 138: p. 67-75.

Fantini, A.E. (2000): A central concern: developing intercultural competence. SIT Occasional Papers Series, 
1. (Online) Elérhetőség: http://www.sit.edu/publications/ docs/competence.pdf. (Letölt.: 2012. augusztus 8.)

Fantini, A.E. (2006): Exploring and assessing intercultural competence. (Online) Elérhetőség: http://www.sit.edu/ publications/docs/feil_research_report.pdf (Letöltés: 2012. július 18.)

Fritz, W. - Möllenberg, A. - Chen, G-M. (é.n.): Measuring intercultural sensitivity in different cultural context. Braunschweig: Technische Universitat. (Online) Elérhetôség: http://www.uri.edu/iaics/content /2002v11n2/12\%20Wolfgang\%20Fritz\%20\&\%20 Antje\%20Mollenberg.pdf (Letöltés: 2012. július 18.)

Greenholtz, J. (2000): Assessing cross-cultural competence in transnational education: the Intercultural Development Inventory. Higher Education In Europe, 25 (3): p. 411416. Academic Search Complete (Online). Elérhetőség: www.ebscohost.com (Letöltés: 2011. december 12.)

Hammer, M.R. (2011): Additional cross-cultural validity testing of the Intercultural Development Inventory. International Journal of Intercultural Relations 35: p. 474-487.

Holmes, P. - O'Neill, G. (2012): Developing and evaluating intercultural competence: ethnographies of intercultural encounters. International Journal of Intercultural Relations, 36(5): p. 707-718.

Hunter, B. - White, G.P. - Godbey, G. (2006): What does it mean to be globally competent? Journal of Studies in International Education, 10(3): p. 267-285.

INCA Project $\mathrm{www}$.incaproject.org

Kim, Y.Y. (2001): Becoming intercultural: an integrative theory of communication and cross-cultural adaptation. Thousand Oaks: Sage

Kim, Y.Y. (1992): Intercultural communication competence: A systems-thinking view. in: Gudykunst, W.B.- Kim, Y.Y. (eds.): Readings on communicating with strangers: an approach to intercultural communication. New York: McGraw-Hill: p. 371-381.

King, P. M. - Baxter Magolda, M.B. (2005): Adevelopmental model of intercultural maturity. Journal of College Student Development, 46(6): p. 571-592. (Online) Elérhetôség: www.scopus.com (Letöltés: 2012. szeptember 15.)

Koltai A. (2009a): Az interkulturális sokk és az ebból fakadó problémák megelőzése. Munkaügyi Szemle, 1.: p. 8189.

Koltai A. (2009b): Interkulturális szúrés a gyakorlatban. Munkaügyi Szemle, 3.: p. 81-89.

Lakatosné T.E. - Dorner H. (2007): Pedagógusok interkulturális kompetenciája nemzetközi partnerségben. Új Pedagógiai Szemle, 57/10.: p. 42-50.

Matsumoto, D. - LeRoux, J. - Ratzlaff, C. - Tatani, H. Uchida, H. - Kim, C. - Araki, S. (2001): Development and validation of a measure of intercultural adjustment potential in Japanese sojourners: The Intercultural Adjustment Potential Scale (ICAPS). International Journal of Intercultural Relations, 25: p. 483-510.
Olson, C.L. - Kroeger, K.R. (2001): Global competency and intercultural sensitivity. Journal of Studies in International Education, 5(2): p. 116-137.

Paige, R.M. (2004): Instrumentation in intercultural training. in: Landis, D. - Bennett, J.M. - Bennett, M.J. (2004): Handbook of intercultural training. 3rd ed. Thousand Oaks: Sage: p. 85-128.

Paige, R.M. - Jacobs-Cassuto, M. - Yershova, Y.A. - DeJaeghere, J. (2003): Assessing intercultural sensitivity: An empirical analysis of the Hammer and Bennett Intercultural Development Inventory. International Journal of Intercultural Relations, 27: p. 467-486.

Piros B. (2006): Az interkulturális dimenzió bevonása a magyar mint idegen nyelv oktatásába. Hungarológiai Évkönyv, 7/1.: p. 90-96.

Sample, S.G. (2009): Intercultural development and the international curriculum. $\mathrm{Az}$ IDI Konferencián elhangzott előadás. Minneapolis, október 29-30. (Online) Elérhetőség: http://www. idiinventory.com/pdf/idi-2011-research-reports.pdf (Letöltés: 2012. június 15.)

Simons, J. - Krols, Y. (2010): Intercultural competence and professional contexts. Az 1. Alkalmazott Interkulturális Kutatás Konferencia előadásai (Graz, Ausztria, április 7-10.) (Online) Elérhetôség: http://www.uni-graz.at/ fAIR/cAIR10/text/procs/Simons_Krols_cAIR10.pdf (Letöltés: 2012. július 18.)

Sinicrope, C. - Norris, J. - Watanabe, Y. (2007): Understanding and assessing intercultural competence: a summary of theory, research, and practice. (Technical report for the Foreign Language Program evaluation project). Second Language Studies, 26(1): p. 1-58. (Online) Elérhetôség: http://www.hawaii.edu/sls/ uhwpes1/26\%281\%29/Norris.pdf (Letölt.: 2012. júl.18.)

Spitzberg, B.H. - Changnon, G. (2009): Conceptualizing intercultural competence. in: Deardorff, D.K. (ed.): The SAGE handbook of intercultural competence. Thousand Oaks: Sage: p. 2-52.

Várhegyi, $\quad V$. (é.n.): Az interkulturális kompetencia megközelítés. Budapest: Artemisszió Alapítvány. Elérhetőség: http://www.artemisszio.hu/downloads/ ic_megkozelites_vegleges.pdf (Letöltés: 2013. március 18.)

Várhegyi V. -Nann S. (é.n.): Az interkulturális kompetenciák azonosítása. Elérhetôség: http://www.adam-europe.eu/ prj/4407/prd/1/1/WP2-WP3_Final_study_HUN.pdf , (Letöltés: 2013. március 18.)

Williams, T.R. (2005): Exploring the impact of study abroad on students' intercultural communication skills: adaptability and sensitivity. Journal of Studies in International Education, 9(4): p. 356-371. 


\section{FÜGGELÉK}

Interkulturális kompetencia leggyakrabban használt méróeszközei

\begin{tabular}{|c|c|c|c|c|}
\hline Angol elnevezés & A mérés tárgya & Eszköz & Hozzáférés & Hivatkozás \\
\hline $\begin{array}{l}\text { Assessment of } \\
\text { Intercultural Competence } \\
\text { (AIC) }\end{array}$ & $\begin{array}{l}\text { Ismeretek, attitúd, készségek és } \\
\text { tudatosság }\end{array}$ & $\begin{array}{l}\text { Több önkitöltőss } \\
\text { kérdőív, interjú }\end{array}$ & A cikk függelékében & Fantini (2006) \\
\hline $\begin{array}{l}\text { Behavioral Assessment } \\
\text { Scale for Intercultural } \\
\text { Communication } \\
\text { (BASIC) }\end{array}$ & $\begin{array}{l}\text { Tiszteletadás; } \\
\text { interakciós tartás; } \\
\text { tudásorientáció; } \\
\text { empátia; énközpontú } \\
\text { szerepmagatartás; } \\
\text { interakció-menedzsment; } \\
\text { bizonytalanságtúrés }\end{array}$ & Önkitöltős kérdőív & $\begin{array}{l}\text { Az eredeti skála } \\
\text { Rubennél (1976) }\end{array}$ & $\begin{array}{l}\text { Olebe - Koester } \\
(1989)\end{array}$ \\
\hline $\begin{array}{l}\text { Cross-cultural } \\
\text { Adaptability Inventory } \\
\text { (CCAI) }\end{array}$ & $\begin{array}{l}\text { Érzelmi rugalmasság; } \\
\text { rugalmasság és nyitottság; } \\
\text { érzékelési pontosság és személyes } \\
\text { autonómia }\end{array}$ & Önkitöltős kérdőív & $\begin{array}{l}\text { Kereskedelmi } \\
\text { forgalomban: www. } \\
\text { creativeorgdesign.com }\end{array}$ & $\begin{array}{l}\text { Kelley - Meyers } \\
(1995)\end{array}$ \\
\hline $\begin{array}{l}\text { Global Competency and } \\
\text { Intercultural Sensitivity } \\
\text { Index (ISI) }\end{array}$ & $\begin{array}{l}\text { Bennett DMIS modellje, valamint } \\
\text { globális kompetencia }\end{array}$ & Önkitöltős kérdőív & Egyes itemek a cikkben & $\begin{array}{l}\text { Olson - Kroeger } \\
(2001)\end{array}$ \\
\hline $\begin{array}{l}\text { Intercultural Adjustment } \\
\text { Potential Scale } \\
\text { (ICAPS-55) }\end{array}$ & $\begin{array}{l}\text { Emóció-szabályozás; } \\
\text { nyitottság; } \\
\text { rugalmasság; } \\
\text { kritikai gondolkodás }\end{array}$ & Önkitöltős kérdőív & $\begin{array}{l}\text { Egyes itemek a } \\
\text { cikkben. Kereskedelmi } \\
\text { forgalomban: www. } \\
\text { humintell.com }\end{array}$ & $\begin{array}{l}\text { Matsumoto et al. } \\
(2001)\end{array}$ \\
\hline $\begin{array}{l}\text { Intercultural } \\
\text { Competency Assessment } \\
\text { (INCA) }\end{array}$ & $\begin{array}{l}\text { Bizonytalanságtúrés; } \\
\text { magatartásbeli rugalmasság; } \\
\text { kommunikációs tudatosság; } \\
\text { más kultúrák megismerése; } \\
\text { másság tisztelete; } \\
\text { empátia }\end{array}$ & $\begin{array}{l}\text { Önkitöltős kérdőív, } \\
\text { forgatókönyv, } \\
\text { szerepjáték }\end{array}$ & A webhelyen & $\begin{array}{l}\text { www.incaproject. } \\
\text { org }\end{array}$ \\
\hline $\begin{array}{l}\text { Intercultural } \\
\text { Development Inventory } \\
\text { (IDI) }\end{array}$ & $\begin{array}{l}\text { Interkulturális érzékenység } \\
\text { (tagadás, védekezés, minimalizálás, } \\
\text { elfogadás, alkalmazkodás, } \\
\text { integráció) }\end{array}$ & Önkitöltős kérdőív & $\begin{array}{l}\text { Kereskedelmi } \\
\text { forgalomban: www. } \\
\text { idiinventory.com }\end{array}$ & $\begin{array}{l}\text { Hammer - Bennett } \\
(1993)\end{array}$ \\
\hline $\begin{array}{l}\text { Intercultural Readiness } \\
\text { Check (IRC) }\end{array}$ & $\begin{array}{l}\text { Interkulturális érzékenység; } \\
\text { kommunikáció, vezetés és } \\
\text { bizonytalanság-kezelés }\end{array}$ & Önkitöltős kérdőív & $\begin{array}{l}\text { Kereskedelmi } \\
\text { forgalomban: www. } \\
\text { ibinet.nl }\end{array}$ & www.ibinet.nl \\
\hline $\begin{array}{l}\text { Intercultural Sensitivity } \\
\text { Inventory (ICSI) }\end{array}$ & $\begin{array}{l}\text { Individualizmus - } \\
\text { kollektivizmus az érzékenység } \\
\text { függvényében; rugalmasság; } \\
\text { nyitottság }\end{array}$ & Önkitöltős kérdőív & Az összes item a cikkben & $\begin{array}{l}\text { Bhawuk - Brislin } \\
(1992)\end{array}$ \\
\hline $\begin{array}{l}\text { Intercultural Sensitivity } \\
\text { Scale (ISS) }\end{array}$ & $\begin{array}{l}\text { Interakció-menedzsment, kulturális } \\
\text { különbség tiszteletben tartása; } \\
\text { interakciós magabiztosság; } \\
\text { interakció élvezete; } \\
\text { interakcióra való odafigyelés }\end{array}$ & Önkitöltős kérdőív & Az összes item a cikkben & $\begin{array}{l}\text { Chen - Starosta } \\
(2000)\end{array}$ \\
\hline
\end{tabular}

Forrás: Berardo (2005), Fantini (2000), Sinicrope, Norris és Watanabe (2007) és személyes közlések 